\section{Cytomegalovirus Disease in Children With Acute Lymphoblastic Leukemia: A Case Series Study}

ilknur Çağlar ๑

ilker Devrim ๑ Özgür Cartı $\odot$

Mine Düzgöl (1)

\author{
Akut Lenfoblastik Lösemili Çocuklarda \\ Sitomegalovirüs Hastalığı: Olgu Serisi
}

Ahu Kara Aksay ®

Bengü Demirağ (1)

Salih Gözmen (1)

Yılmaz Ay (1)

Tuba Hilkay Karapınar $\mathbb{}$

Nuri Bayram (1)

Yeşim Oymak (1)

Canan Vergin (D

\section{ABSTRACT}

Objective: There are limited data focusing on incidence and manifestations of cytomegalovirus (CMV) in children with acute lymphoblastic leukemia (ALL) apart from bone marrow transplant recipients. In this study, we aimed to review our experience regarding the manifestations, treatment, and outcome of cytomegalovirus infection in pediatric ALL patients.

Methods: We retrospectively reviewed the clinical characteristics of patients with ALL that were diagnosed with CMV disease while they were on standard chemotherapy.

Results: Fourteen patients were included in the std. Fever was the most common symptom (64\%). Eyes, lungs and liver were the most commonly involved organs in CMV disease. Lymphopenia was found in most of the patients. At the time of diagnosis, $50 \%$ of the patients were on maintenance phase of chemotherapy. All patients were treated with intravenous ganciclovir. Two patients died because of concomitant infections, and two children with retinitis had permanent visual sequelae while others had a complete recovery.

Conclusion: In children with ALL, CMV is an important pathogen with serious consequences including retinitis which may be asymptomatic and result in complete visual loss. Not only during intense chemotherapy but also in maintenance phase CMV disease may occur. Especially when prolonged ( $>7$ days) febrile neutropenia and lymphopenia is present, CMV must be kept in mind in the differential diagnosis.

Keywords: Febrile neutropenia, cytomegalovirus, child, acute lymphoblastic leukemia

\section{öz}

Amaç: Kemik iliği transplant alıcısı olanlar dışında akut lenfoblastik lösemili (ALL) çocuklarda sitomegalovirüs (CMV) insidansı ve bulguları hakkında sınırlı veri bulunmaktadır. Bu çalışmada, pediatrik ALL hastalarında sitomegalovirüs enfeksiyonunun klinik tablosu, tedavisi ve sonuçları hakkındaki deneyimlerimizin gözden geçirilmesi amaçlanmıştır.

Yöntem: Standart kemoterapi almaktayken CMV hastalığı tanısı konan ALL hastalarının klinik özellikleri retrospektif olarak incelendi.

Bulgular: On dört hasta çalıșmaya dahil edildi. En sık görülen semptom atești (\%64). Sitomegalovirus hastalığında en sık etkilenen organlar göz, akciğerler ve karaciğerdi. Lenfopeni, hastaların çoğunda mevcuttu. Tanı anında hastaların \%50'si kemoterapinin idame safhasındaydı. Tüm hastalar intravenöz gansiklovir ile tedavi edildi; iki hasta eşzamanlı enfeksiyonlar nedeniyle kaybedildi, retinitis olan iki çocukta kalıcı görme kaybı gelişti ve diğerleri tamamen iyileşti.

Sonuç: Sitomegalovirüs, asemptomatik olabilen ve tam görme kaybı ile sonuçlanabilen retinit dahil, ALL hastalarında ciddi sonuçları olan bir patojendir. Yalnızca yoğun kemoterapi sırasında değil, kemoterapinin idame safhasında da CMV hastalığı gelişebilir. Özellikle uzamış (>7 gün) febril nötropeni ve lenfopeni varsa, ayırıcı tanıda CMV akılda tutulmalıdır.

Anahtar kelimeler: Febril nötropeni, sitomegalovirüs, çocuk, akut lenfoblastik lösemi
Alındığı tarih: 10.10 .2018

Kabul tarihi: 07.02.2019

Online Yayın tarihi: 06.12.2019

ilknur Çağlar

Sağlık Bilimleri Üniversitesi Dr. Behçet

Uz Çocuk Hastalıkları ve Cerrahisi Eğitim ve Araştırma Hastanesi, Çocuk Enfeksiyon Hastalıkları Kliniği, İzmir - Türkiye

dr_ilknur@yahoo.com ORCID: 0000-0003-3508-3531

i. Devrim 0000-0002-6053-8027

M. Düzgöl 0000-0002-3190-2950 A. Kara Aksay 0000-0002-5233-0285 Sağlık Bilimleri Üniversitesi Dr. Behçet

Uz Çocuk Hastalıkları ve Cerrahisi

Eğitim ve Araștırma Hastanesi, Çocuk Enfeksiyon Hastalıkları Kliniği, Izmir, Türkiye

Ö. Cartı 0000-0002-7604-6481 Adnan Menderes Üniversitesi, Çocuk Hematoloji ve Onkoloji Anabilim Dalı, Aydın, Türkiye

B. Demirağ 0000-0003-4399-0844 S. Gözmen 0000-0002-8585-9628 Y. Ay 0000-0002-5525-5647 T. Hilkay Karapınar 0000-0002-4714-332X

N. Bayram 0000-0003-1802-2518

Y. Oymak 0000-0002-6908-8309

C. Vergin 0000-0002-4995-3852

Sağlık Bilimleri Üniversitesi Dr. Behçet

Uz Çocuk Hastalıkları ve Cerrahisi

Eğitim ve Araştırma Hastanesi,

Çocuk Hematoloji ve Onkoloji Kliniği,

izmir, Türkiye

Bu çalışma, 29 Eylül-2 Ekim 2016 tarihleri arasında Eskişehir'de 1. Ulusal Çocuk Enfeksiyon Hastalıkları Sempozyumu'nda sunulmuştur. 


\section{INTRODUCTION}

Cytomegalovirus (CMV) is a common pathogen with a high prevalence worldwide; at least $60-80 \%$ of the World population gets infected with CMV until they reach adulthood. It manifests in different clinical presentations in different populations. Immunocompetent individuals mostly have mild or asymptomatic disease but immunocompromised patients, as solid organ (SOT), and hematopoietic stem cell transplant (HSCT) recipients, immunosuppressive drug receivers and HIV-infected people, may face severe forms of CMV infection causing high morbidity and mortality ${ }^{(1)}$. These conditions are mostly related to T-cell dysfunction. Whatever the primary disease is, T-cell mediated immune dysfunction plays an important role in the pathogenesis of severe CMV infections. The studies on CMV infection in immunosuppressed patients are generally based on well-demonstrated conditions such as HSCT and SOT, however, there are limited studies about incidence and manifestations of CMV in children with ALL receiving standard chemotherapy ${ }^{(2,3)}$. Here we report our clinical experience with fourteen ALL patients that had CMV disease as detected during their monitorization.

\section{MATERIAL and METHODS}

The Hematology and Oncology Department of Dr. Behçet Uz Children's Hospital is a 22-bed unit with annual circulation of 60 patients with leukemia. This cross-sectional study included the cases that were admitted to Hematology and Oncology Department and Pediatric Infectious Disease Department during the period between November 2012 and December 2016 and diagnosed with CMV disease. All admitted patients were identified using both hospital and unit-specific databases. Existence and duration of fever, organ involvement, hematologic parameters, phase of chemotherapy, serology status of CMV at the initiation of chemotherapy, and the results of quantitative polymerase chain reaction (PCR) (QiagenArtus CMV QS-RGQ test) analyzed from blood samples obtained at the time of diagnosis of CMV disease and response to antiviral therapy of all patients were recorded into a registry form.

Definitions: Diagnosis of cytomegalovirus disease was made according to standard definitions (4). Infection is defined as symptomatic (existence of fever without organ involvement) or asymptomatic. End-organ dysfunction (gastrointestinal tract, liver, lung, eye, and uncommonly central nervous system or cardiovascular system dysfunction) in the presence of CMV viremia documented with laboratory tests was defined as CMV disease. Diarrhea, increased transaminase levels with relevant ultrasonographic findings, unresolved pneumonia accompanied by features of viral pneumonia (mixed alveolarinterstitial infiltrates such as ground-glass opacity, poorly-defined centrilobular small nodules, consolidation, bronchiectasis, bronchial wall thickening, and interstitial reticulation) on computed tomography with negative multiplex PCR results for other respiratory pathogens, loss of visual acuity, and chorioretinitis findings on fundoscopy were investigated for organ involvement. Hematologic manifestations for cytopenias were defined as neutropenia ( absolute neutrophil count $(\mathrm{ANC})<500 / \mu \mathrm{L}$ ), lymphopenia (absolute lymphocyte count $(\mathrm{ALC})<1000 / \mu \mathrm{L}$ ), thrombocytopenia (platelet count $<100,000 / L$ ) and anemia (hemoglobin level less than the $5^{\text {th }}$ percentile for age).

Quantitative CMV polymerase chain reaction (PCR) test results obtained from blood sample, and the agent, duration, outcomes and adverse reactions of antiviral therapy were reviewed from clinical data and recorded in a form.

\section{Statistical analysis}

Statistical analysis of data was performed with Statistical Package for Social Sciences (SPSS) for Windows (Inc. Chicago, the USA, 2001, version 15.0). The quantitative data were described as the means and standard deviation (SD) or medians with interquartile range (IQR), according to normal reference values.

All procedures performed in the study were in accordance with the ethical standards of the institutional research committee and with the 1964 Helsinki 
Declaration and its later amendments or comparable ethical standards.

This is a retrospective chart review study and any intervention was not planned. Hence in accordance of confidentiality protocol of the institute, no additional informed consent was obtained from the patient after approval from the institutional ethical committee was obtained.

\section{RESULTS}

Fourteen ALL patients who had CMV disease were included in the study. Median age was 2 years (2-9.5 years). Fifty percent of the cases were in the maintenance phase of chemotherapy. Clinical features, duration and outcome of antiviral treatment of ALL children with CMV disease are summarized in Table 1. Fever was the most common symptom (64\%) with unknown origin and/or prolonged duration despite administration of appropriate wide spectrum antibiotic and antifungal therapy. Elevated transaminase level of unexplained etiology was present in 7 patients (50\%). At the time of diagnosis, the most common hematologic finding was lymphope-

Table 1. Clinical features and outcome of ALL patients diagnosed with CMV disease.

\begin{tabular}{|c|c|c|c|c|c|c|c|c|}
\hline $\begin{array}{l}\text { Patient } \\
\text { No/Age/Sex }\end{array}$ & $\begin{array}{l}\text { Chemotherapy } \\
\text { Protocol }\end{array}$ & $\begin{array}{l}\text { Time of CMV } \\
\text { disease }\end{array}$ & Symptom & $\begin{array}{l}\text { ANC/ALC at } \\
\text { diagnosis } \\
\text { (per } \mu \mathrm{L})\end{array}$ & $\begin{array}{l}\text { CMV DNA at } \\
\text { diagnosis } \\
\text { (copies/ml) }\end{array}$ & $\begin{array}{l}\text { Organ } \\
\text { involvement }\end{array}$ & Treatment & Outcome \\
\hline 1/M/9y & IDA-FLAG & $\begin{array}{l}5^{\text {th }} \text { mo of } \\
\text { maintenance }\end{array}$ & Fever & $1200 / 200$ & 67936 & Eye & $\begin{array}{l}\text { IV G:3mo } \\
\text { PO VG:8mo }\end{array}$ & $\begin{array}{l}\text { Permanent visual } \\
\text { defect }\end{array}$ \\
\hline $2 / F / 7 y$ & ST JUDE TOTAL XV & $\begin{array}{l}1^{\text {st }} \text { mo of } \\
\text { maintenance }\end{array}$ & $\begin{array}{l}\text { Visual } \\
\text { disturbance }\end{array}$ & $600 / 200$ & 433062 & Eye & IV G:49d & $\begin{array}{l}\text { Permanent visual } \\
\text { defect }\end{array}$ \\
\hline $3 / F / 2 y$ & ALL IC BFM 2009 & During reinduction & Fever & $0 / 100$ & 1736 & Liver & IV G:5d & Died (Sepsis)* \\
\hline 4/M/7mo & ALL IC BFM 2009 & During consolidation & Fever & $2700 / 400$ & 204 & - & IV G:25d & Complete response \\
\hline 5/M/11mo & ALL IC BFM & During induction & Fever & $240 / 280$ & 159 & - & IV G:7d & Died (Pneumonia)\# \\
\hline $6 / F / 4 y$ & ALL IC BFM 2009 & During consolidation & - & $10 / 930$ & 154 & - & IV:13d & Complete response \\
\hline $7 / F / 2 y$ & ALL IC-BFM 2009 & $\begin{array}{l}18^{\text {th }} \text { mo of } \\
\text { maintenance }\end{array}$ & - & $1820 / 210$ & 129 & - & IV G:22d & Complete response \\
\hline $8 / F / 11 y$ & ALL-REZ BFM 2002 & $\begin{array}{l}11^{\text {th }} \text { mo of } \\
\text { maintenance }\end{array}$ & Fever & $1500 / 760$ & 83 & Liver & IV G:7d & Complete response \\
\hline 9/F/3y & ALL IC-BFM 2009 & During induction & Fever & $550 / 620$ & 96 & Lung & IV G:6 d & Complete response \\
\hline 10/F/7y & ALL IC-BFM 2009 & $\begin{array}{l}4^{\text {th }} \text { mo of } \\
\text { maintenance }\end{array}$ & Fever & $90 / 620$ & 20168 & - & IV G:35d & Complete response \\
\hline $11 / M / 1,5 y$ & ALL IC-BFM 2009 & During induction & Fever & $1210 / 810$ & 125 & Lung & IV G.12 d & Complete response \\
\hline $12 / M / 14 y$ & ALL IC-BFM 2009 & $\begin{array}{l}11^{\text {th }} \text { mo of } \\
\text { maintenance }\end{array}$ & - & $480 / 3260$ & 457 & Eye & IV G:35 d & Complete response \\
\hline 13/M/10y & ALL IC BFM 2009 & During reinduction & - & $1870 / 310$ & 170 & Liver & IV G:13d & Complete response \\
\hline $14 / M / 4 y$ & ALL IC-BFM 2009 & $\begin{array}{l}4^{\text {th }} \text { mo of } \\
\text { maintenance }\end{array}$ & Fever & $7850 / 250$ & 911 & Lung & IV G:11d & Complete response \\
\hline
\end{tabular}

M: Male, F: Female, y: year, mo: month, CMV: Cytomegalovirus, ANC: Absolute neutrophile count, ALC: Absolute lymphocyte count, IV:Intravenous, PO:Per oral, G: Ganciclovir, VG:Valganciclovir

*Blood culture was positive for Klebsiella pneumonia. ESBL.

\#Parainfluenza and Respiratory syncytial virus were detected with multiplex PCR, blood cultures were sterile. 
nia (92\%). Only one patient had negative CMV IgG result; others were positive for CMV IgG. Cytomegalovirus viremia was shown with PCR in all patients. Isolated organ involvement was seen in 9 patients including cases with hepatosplenic disease $(n=3)$; pneumonia $(n=3)$ and ocular involvement $(n=3)$. Two patients ( 7 and 14 years old) with CMV retinitis had uniocular and one patient (9 years old) had bilateral ocular involvement. Only the 7 year old patient was symptomatic with loss of visual acuity in one eye. All patients received intravenous ganciclovir at a dose of $7 \mathrm{mg} / \mathrm{kg}$ twice a day for 17, 5 days (IQR: 7-35 days). In one case with retinitis, valganciclovir treatment was continued for 8 months, until CMV DNA-negativity was achieved. All cases were followed up with repeated ophthalmologic evaluation and CMV PCR tests. Negative CMV PCR result was obtained in twelve patients who had survived (86\%). Mortality rate within seven days was $14 \%$; and two children died on the 5th and 7th days of their antiviral therapy due to multiorgan dysfunction and pneumonia respectively, despite appropriate empiric antibacterial and antifungal treatment. In addition to $\mathrm{CMV}$; the first patient had positive blood culture for multidrug resistant Klebsiella pneumonia, and the second one had parainfluenza and respiratory syncytial virus in respiratory secretions detected on multiplex PCR. Renal injury was observed as an adverse reaction of ganciclovir in one patient. No other side effects were observed attributable to ganciclovir therapy during treatment.

\section{DISCUSSION}

In Turkey, incidence of CMV infection is very high (97.6\%); and seropositivity was shown approximately in $90 \%$ of people under 20 years old ${ }^{(5)}$. In one study, CMV antigenemia for hematologic malignancies had been shown at a rate of \%11 ${ }^{(6)}$. Jain et al. ${ }^{(2)}$ had found a $10 \%$ risk of CMV infection in their study performed in children with ALL and prolonged febrile neutropenia. Thirteen of fourteen patients in our study had positive CMV IgG results which were considered as reactivation of CMV. The patient with negative CMV IgG result was assumed as initial CMV infection. With respect to the relatively high rate of CMV infection in our country and experience from this study, ALL patients should be considered as a risk group for CMV disease.

Cytomegalovirus disease may have nonspecific manifestations as fever, malaise, abnormal blood counts, elevated transaminases; and also serious outcomes like hepatitis, colitis, pneumonitis, retinitis or even death in immunocompromised patients. In the literature, fever had been shown as the most common symptom of CMV disease in children with ALL ${ }^{(2,3)}$. In our study, fever (64\%) was found as the most common symptom supporting previous studies. Especially in the presence of prolonged febrile neutropenia persisting for more than 7 days, CMV should be kept in mind in the differential diagnosis $(2,3,7)$. Neutropenia and thrombocytopenia associated with CMV infection in children with ALL receiving standard chemotherapy were also reported in an article ${ }^{(8)}$. Also, lymphopenia was demonstrated in these patients and cited to be a risk factor for the development of CMV infection. It has been assumed that recurrence risk of CMV was higher with prolonged and profound lymphopenia ${ }^{(2,3)}$. In our study, we found lymphopenia at a rate of $92 \%$ as well. Thrombocytopenia was the second common blood count abnormality (71\%). Unexplained and prolonged lymphopenia may be considered as a warning sign to suspect CMV infection in these patients.

Most severe infections occur during the induction phase of treatment in pediatric ALL patients due to immunosuppression by intense chemotherapy ${ }^{(9,10)}$. Recent reports showed that CMV disease might occur also in the maintenance phase of chemotherapy in children with ALL ${ }^{(2,3)}$. This may be in association with the altered T-cell immunity of these patients ${ }^{(11)}$. In our study, $50 \%$ of the patients were in the maintenance phase.

In the literature, organ involvement in CMV disease mostly consisted of ocular and pulmonary involvement in children with ALL followed by with lesser involvement of gastrointestinal and hepatosplenic system ${ }^{(2,3)}$. In our case series, hepatosplenic disease, pneumonia and ocular involvement were the most common presentations of CMV disease. Chorioretinitis 
associated with CMV in children with ALL has been increasingly reported during recent years. Up to our knowledge, only 17 cases were cited in the English literature. Fourteen of them (82\%) were diagnosed in the maintenance phase of chemotherapy, and five (29\%) cases had not any visual complaints. Permanent visual defect developed in five patients and two patients had retinal detachment ${ }^{(2,3,7,8)}$. There were three patients with CMV retinitis in our study and all of them were in the maintenance phase. Although they were old enough to express visual changes, only one complained about loss of visual acuity; and the other two patients were asymptomatic. One of the patients had asymptomatic bilateral retinitis and despite antiviral therapy, retinitis sequelae and permanent visual defect developed. The second asymptomatic patient with unilateral retinitis recovered completely. The symptomatic patient describing unilateral visual loss had retinitis at the same eye and recovered partially with antiviral therapy. When CMV is detected, even though there is no visual symptom, chorioretinitis must be carefully evaluated and treated promptly in these patients because of its devastating outcomes.

All of our patients received intravenous ganciclovir therapy. But one patient received valganciclovir as maintenance treatment that continued for 8 months. Treatment of CMV disease in ALL patients is not standardized and different treatment modalities have been reported. Recently, Jain et al recommended parenteral ganciclovir therapy for a period of 14-21 days to prevent reactivation of CMV. In their study mortality rate was $10 \%$, and there were two patients with permanent visual defect (2). In our study, nine patients achieved complete recovery at the end of therapy, but two had permanent visual defects. Relapse was observed only in one patient after ceasing therapy during follow up. Two cases had concomitant infections and died due to multiorgan dysfunction. Higher morbidity and mortality rates were reported in the literature due to $\mathrm{CMV}$ in these patients ${ }^{(12)}$. From this aspect, CMV monitoring and preemptive strategies in children with ALL might be important especially for HSCT and SOT patients.

\section{CONCLUSION}

There are still limited data about CMV manifestations in children with ALL. In our study retinitis was found to be an important complication of CMV infection. It may be asymptomatic and result in complete visual loss. Not only the patients in intense chemotherapy but also the patients in the maintenance phase had a great risk for CMV disease. In the presence of prolonged ( $>7$ days) febrile neutropenia and lymphopenia, CMV disease should be kept in mind in the differential diagnosis.

Ethics Committee Approval: T. C. Ministry of Health, Public Hospitals Authority Turkey Izmir Province Public Hospitals Union General Secretariat of the Southern District S.B.Ü. Izmir Behçet Uz Pediatric Training and Research Hospital Clinical Research Ethics Committee approval was obtained (2017/12-06).

Conflict of Interest: The authors declare that there is no conflict of interest.

Funding: No financial support was received from any institution or person for the research.

Informed Consent: Since the study was retrospective, informed consent was not obtained from the patients.

Etik Kurul Onayı: T.C. Sağlık Bakanlığı Türkiye Kamu Hastaneleri Kurumu İzmir Illi Kamu Hastaneleri Birliği Güney Bölgesi Genel Sekreterliği S.B.Ü. İzmir Dr. Behçet Uz Çocuk Hastalıkları ve Cerrahisi Eğitim ve Araştırma Hastanesi Klinik Araştırmalar Etik Kurulu onayı alınmıştır (2017/12-06).

Çıkar Çatışması: Yazarlar çıkar çatışması olmadığını beyan eder.

Finansal Destek: Araştırma için herhangi bir kurum ya da kişiden finansal destek alınmamıştır.

Hasta Onamı: Araştırma retrospektif bir dosya taraması olduğu için hasta onamı alınmamıştır.

\section{REFERENCES}

1. GJ H. Cytomegalovirus. Feigin and Cherry's Textbook of Pediatric Infectious Diseases. $7^{\text {th }}$ Ed., Philadelphia, Elsevier Saunders. 2014;1969 .

2. Jain R, Trehan A, Mishra B, Singh R, Saud B, Bansal D. 
Cytomegalovirus disease in children with acute lymphoblastic leukemia. J Pediatr Hematol Oncol. 2016;33:239-47. https://doi.org/10.3109/08880018.2016.1173147

3. Rahbarimanesh $A$, Ehsani $M$, Karahroudi $M$, Rashidi $A$, Aghajani M, Meysami A, et al. Cytomegalovirus Disease in Children With Acute Lymphoblastic Leukemia in the Nontransplant Setting: Case Series and Review of the Literature. J Pediatr Hematol Oncol. 2015;37:429-32. https://doi.org/10.1097/MPH.0000000000000298

4. Ljungman $\mathrm{P}$, Boeckh $\mathrm{M}$, Hirsch $\mathrm{HH}$, Josephson $\mathrm{F}$, Lundgren J, Nichols G, et al. Definitions of Cytomegalovirus Infection and Disease in Transplant Patients for Use in Clinical Trials. Clin Infect Dis. 2017;64(1):87-91. https://doi.org/10.1093/cid/ciw668

5. Coskuner SA, Avci M, Ozsu S, Tosun S. The evaluation of the relationship between CMV IgG positivity and age. Medical Journal of Izmir Hospital. 2014;18(4):100-3.

6. Han XY. Epidemiologic analysis of reactivated cytomegalovirus antigenemia in patients with cancer. J Clin Microbiol. 2007;45:1126-32. https://doi.org/10.1128/JCM.01670-06

7. Demir SÖ, Çeliker H, Karaaslan A, Kadayifci EK, Akkoç G, Atıcı $S$, et al. Cytomegalovirus Retinitis in Three Pediatric Cases with Acute Lymphoblastic Leukemia: Case Series and Review of the Literature. Jpn J Infect Dis. 2016;69(6):534-8.
https://doi.org/10.7883/yoken.JJID.2015.223

8. Kanvinde S, Bhargava P, Patwardhan S. Cytomegalovirus infection as a cause of cytopenia after chemotherapy for hematological malignancies. Indian Pediatr. 2013;50:197201. https://doi.org/10.1007/s13312-013-0066-4

9. Luczynski W, Stasiak-Barmuta A, Krawczuk-Rybak M, Zak J. Immunologic monitoring in children with acute lymphoblastic leukemia during maintenance treatment with regard to co-existing infections. Wiad Lek. 2004;57:337-42.

10. Gulia S, Dangi U, Biswas S, Kelkar R, Menon H, Sengar M. Prevalence and patterns of cytomegalovirus DNAemia in adult patients with acute lymphoblastic leukemia on chemotherapy. Leuk Lymphoma. 2014;55:1209-11. https://doi.org/10.3109/10428194.2013.825372

11. Lovat PE, Robinson JH, Windebank KP, Kernahan J, Watson JG. Serial study of T lymphocytes in childhood leukemia during remission. Pediatr Hematol Oncol. 1993;10:129-39. https://doi.org/10.3109/08880019309016546

12. Torres HA, Kontoyiannis DP, Aguilera EA, Younes A, Luna MA, Tarrand JJ, et al. Cytomegalovirus infection in patients with lymphoma: an important cause of morbidity and mortality. Clin Lymphoma Myeloma. 2006;6:393-8. https://doi.org/10.3816/CLM.2006.n.016 